\title{
Fear of Covid-19 Related Factors among Females in Indonesia: An Online Survey
}

\author{
Roxsana Devi Tumanggor ${ }^{1 *} \oplus$, Intan Imaroh $^{2} \odot$, Andrew Cashin ${ }^{3} \odot$ \\ ${ }^{1 *}$ Faculty of Nursing, Community and Psychiatric Nursing Department, Universitas \\ Sumatera Utara, Medan, Indonesia \\ ${ }^{2}$ Faculty of Public Health, Statistics and Populations Department, Universitas \\ Sumatera Utara, Medan, Indonesia \\ ${ }^{3}$ School of Health and Human Sciences, Faculty of Health, Southern Cross University, \\ East Lismore NSW, Australia
}

\section{Gopen access}

\section{Jurnal Keperawatan Padjadjaran (JKP)}

Volume 9(3), 216-223

(C) The Author(s) 2021

https://doi.org/10.24198/jkp.

v9i3.1875

\section{Article Info}

Received : November 04, 2021

Revised : December 07, 2021

Accepted : December 14, 2021

Published : December 29, 2021

Corresponding author

Roxsana Devi Tumanggor Faculty of Nursing, Community and Psychiatric Nursing Department, Universitas Sumatera Utara Medan, Indonesia, 20524, Phone: 6281910819799 , E-mail: roxsana.tumanggor@usu.ac.id

Citation

Tumanggor, R.D., Imaroh, I., \& Cashin, A. (2021). Fear of Covid-19 Related Factors among Females in Indonesia: An Online Survey. Jurnal Keperawatan Padjadjaran, 9(3), 216-223.

https://doi.org/10.24198/jkp. v9i3.1875

\section{Website}

http://jkp.fkep.unpad.ac.id/index. php/jkp

This is an Open Access article distributed under the terms of the Creative Commons Attribution-NonCommercial 4.0 International License.

E-ISSN: 2442-7276

P-ISSN: 2338-5324

\begin{abstract}
Background: The COVID-19 pandemic is a highly infectious flu outbreak which spread rapidly around the world. COVID-19 outbreak caused panic and is predicted to increase the prevalence of mental illnesses such as depression and anxiety disorder. Along with increased anxiety and decreased mood, increased fear has been detected.

Purpose: To analyze the fear of COVID-19 related factors and measure the level of fear among women in Indonesia.

Methods: This is a cross-sectional study with 242 women who was implemented using the fear of COVID-19 instrument. A convenience sample was utilized and was recruited via an online WhatsApp through personal text to the potential respondents. The respondents stated their agreement to participate on the Google form before proceeding to fill in the data and answer the instrument items. The analysis was carried out to obtain the frequency distribution, mean and $\mathrm{P}$-value. The mean score of each instrument item and the overall items were calculated and compared based on demographic data using t-test for two variables and analysis of variance (ANOVA) for three or more variables. Furthermore, the scores obtained were categorized into low and high fear levels based on the overall mean, where scores from 0-17 were categorized as low-level fear and 18-35 as high-level fear.

Results: The results showed that $90.9 \%$ of the respondents were within the age range of 15-25 years, with the majority being students. Based on the results of statistical tests, it was discovered that question 3 (Q3) and question 4 (Q4) were the two items that affected the level of women's fear to COVID-19. Furthermore, the results of statistical tests using ANOVA showed that occupation (P-Value of 0.01 ) and age (P-Value of 0.004$)$ has a significant effect on the fear of COVID-19. In addition, based on the overall score calculation showed that $72.3 \%$ samples have high-level fear and $27.7 \%$ has low-level fear. Based on the results of this study, it was discovered that women's age and occupation influence the level of fear to COVID-19.

Conclusion: This study highlighted the significance of pandemic related fear and can inform the development of future women's health studies.
\end{abstract}

Keywords: fear of covid-19; female; cross sectional study; online survey; indonesia; covid-19 scale.

\section{Introduction}

The CoronavirusDisease (COVID-19) is caused by a virus that was discovered in China at the end of 2019 and has rapidly spread throughout the world including Indonesia. Lockdowns were imposed in many countries to control the spread of the virus. People had to stay at home, to learn and work online because the space for movement and direct interaction was often limited. Many individuals all over the world were affected in various aspects, ranging from socio-economic (Nicola et al., 2020), to mental disorder symptoms (Cullen et al., 2020).

Studies have shown that some people experienced anxiety, depression and sleep problems during the COVID-19 pandemic (Y. Huang \& Zhao, 
2020). In addition, social restraint associated with the response to the COVID-19 pandemic has led to feelings of loneliness, fear, anger and depression in some cases (Xiang et al., 2020). This is certainly an issue of concern, as the increase in anxiety, for example, has been as high as a $50 \%$.

Fear is a subjective human response to an uncertain threat (Mikkola et al., 2017). It is associated with physiological symptoms such as sleep disturbances and psychological symptoms such as feeling threatened, worry related to impending of death etc. As a normal response to a danger stimulus, some people have shown the symptoms of fear during the COVID-19 pandemic. Research has identified that fear of COVID-19 is strongly related to the media exposure (Mertens et al., 2020). The use of social media, the search for more information about COVID-19 and regular checks of professional websites increase the individual's fear of COVID-19. It is a situation in which the media plays an important role in inducing people's worry and creates a threatening stimuli for those who are suffering from fear and anxiety symptoms (Lissek et al., 2006). Obviously, the fear and anxiety related to COVID-19 were found to have increased in the early 2020 (Mertens et al., 2020), and to affect people from various groups, both men and women.

Research has identified that fear was frequently the initial psychological distress experienced in the early pandemic outbreak in 2020 (Cullen et al., 2020). Some specific characteristics have been found to be associated with increased fear of COVID-19, such as gender, age and media exposure (Garfin et al., 2020). Research has identified that being female has been associated with increased feelings of fear during pandemic (Broche-Pérez $Y$ et al., 2020), as well as identifying increased symptoms of anxiety and depression in women as compared to men (Rossi et al., 2020). This was contributed by factors such as the nature of women's work and the risk of exposure that is directly affected by COVID-19. The deterioration of the financial sector is impacting women more directly, online learning and the impact of lockdowns (Nicola et al., 2020). The significance of the identified fear responses experienced the need to explore it further.

Several studies have been attempted to provide specific measurements to describe fear (Lebel et al., 2020). Specifically related to COVID-19, a fear of COVID-19 instrument has been developed (Ahorsu et al., 2020) to measure the fear due to COVID-19 and has been tested on various populations in many countries, such as Malaysia, Eastern Europe and Turkey (Pang et al., 2020; Reznik et al., 2020; Satici et al., 2020). The studies found that the instrument of fear of COVID-19 is considered valid with the range from 0.75 to 0.9 in these three countries.

Research conducted by (Doshi et al, 2020) showed that women have shown a higher level of fear of COVID-19 compared to men. This study was conducted in Indian population with 1499 participants that consisted of males and females. Seven items of fear of COVID-19 were utilized (Ahorsu et al., 2020), and comparison was made across six variables of participant characteristics, that included age, gender, marital status, educational background, health care worker status and state of residence. The results revealed that gender and the status of being health care professionals had significance. On the level of fear, females showed higher fear levels as compared to males. It is important to assess the level of fear of COVID-19 as well as the contributing factors, in order to form the basis of planning specific interventions based on certain characteristics (Tracy et al., 2011). BrochePérez $Y$ et al., (2020), using the fear of COVID-19 instrument, researched 772 Cuban participants which consisted of 569 females and 203 males. The participant's characteristics were compared to the instrument's items and identified that females experienced fear of COVID-19 three times more as compared to men. Both studies that used the fear of COVID-19 tool and compared the findings from males and females identified that being a female was associated with a higher fear of COVID-19. Another study related to mental health issues during COVID-19 pandemic identified that there was a difference in outcomes across psychological issues between males and females (Pieh et al., 2020). Females were found to be more vulnerable, to suffer from more sleep problems, anxiety and depression symptoms during the pandemic. These two researches involved both sexes as the research samples and showed that women experienced fear of COVID-19 more compared to men. Therefore, it is needed to conduct a research to analyze the fear of COVID-19 related factors and measure the level of fear among women in Indonesia, since there is no research conducted to measure fear of COVID-19 in Indonesia and the research focusing on women as one of the affected groups during pandemic according to some studies.

\section{Methods}

A This was a research with a cross-sectional study, with the aim of describing the level of women's fear and analyzing the contributing factors using the fear of COVID-19 instrument, which has been proven to be reliable and valid in assessing the level of fear of the general population (Conti et al., 2020). Data collection was carried out by distributing the fear of COVID-19 instrument online, which comprised of 7 questions (Ahorsu et al., 2020). The instrument passed the validity test with 0.66 to 0.74 and reliability test with 0.82 . The authors conducted validity and reliability test with Indonesian instrument. According to the validity test, it is found that $r i>r$ based on the significance test 0.05 , meaning that all items was valid. The reliability test showed that the value of Cronbach Alpha was 0.754, meaning all items was reliable. Using the convenience sampling method, a total of 242 women from all regions of Medan, 
Fear of Covid-19 Related Factors among Females

Table 1. Respondent's Characteristics

\begin{tabular}{lc}
\hline \multicolumn{1}{c}{ Demographics } & $\mathbf{n}(\%)$ \\
\hline Age & $220(90.9)$ \\
$15-25$ & $15(6.2)$ \\
$26-35$ & $5(2.1)$ \\
$36-45$ & $2(0.8)$ \\
$46-55$ & \\
Occupation & $179(74)$ \\
Student/College Student & $8(3.3)$ \\
Unemployment & $22(9.1)$ \\
Nurse & $12(5.0)$ \\
Lecturer/Teacher & $13(5.4)$ \\
Employee/Freelance & $2(0.8)$ \\
Nun & $3(1.2)$ \\
Housewife & $3(1.2)$ \\
Civil servants & \\
The ClosestPersonAffected by COVID-19 & $51(21.1)$ \\
Present & $191(78.9)$ \\
Absent & \\
Comorbidities & $27(11.2)$ \\
Present & $215(88.8)$ \\
Absent & \\
Fear of COVID-19 & $67(27.7)$ \\
Low & $175(72.3)$ \\
High &
\end{tabular}

Table 2. Fear of COVID-19 Instrument Question Items

\begin{tabular}{|c|c|c|c|c|c|c|}
\hline No & Question Items & $\begin{array}{c}\text { Strongly } \\
\text { Disagree (1) }\end{array}$ & Disagree (2) & $\begin{array}{l}\text { Less Dis- } \\
\text { agree ( } 3 \text { ) }\end{array}$ & Agree (4) & $\begin{array}{l}\text { Strongly } \\
\text { agree (5) }\end{array}$ \\
\hline Q1 & $\begin{array}{l}\text { I am most afraid of the } \\
\text { COVID-19 virus }\end{array}$ & $8(3,3)$ & $21(8.7)$ & $48(19.8)$ & $100(41,3)$ & $65(26.9)$ \\
\hline Q2 & $\begin{array}{l}\text { I feel uncomfortable } \\
\text { when thinking about the } \\
\text { COVID-19 virus }\end{array}$ & $10(4.1)$ & $24(9.9)$ & $34(14.0)$ & $124(51.2)$ & $50(20.7)$ \\
\hline Q3 & $\begin{array}{l}\text { My hands become } \\
\text { moist when I think of the } \\
\text { COVID-19 virus }\end{array}$ & $24(9.9)$ & $150(62.0)$ & $44(18.2)$ & $22(9.1)$ & $2(0.8)$ \\
\hline Q4 & $\begin{array}{l}\text { I am afraid to die of the } \\
\text { COVID-19 virus }\end{array}$ & $19(7.9)$ & $57(23.6)$ & $57(23.6)$ & $78(32.2)$ & $31(12.8)$ \\
\hline Q5 & $\begin{array}{l}\text { I get nervous when I watch } \\
\text { news and stories about the } \\
\text { COVID-19 virus on social } \\
\text { media }\end{array}$ & $22(9.1)$ & $80(33.1)$ & $74(30.6)$ & $55(22.7)$ & $11(4.5)$ \\
\hline Q6 & $\begin{array}{l}\text { I could not sleep because } \\
\text { I was worried about the } \\
\text { COVID-19 virus }\end{array}$ & $42(17.4)$ & $114(47.1)$ & $61(25.2)$ & $23(9.5)$ & $2(0.8)$ \\
\hline Q7 & $\begin{array}{l}\text { My heart flutters when I } \\
\text { think of the COVID-19 virus }\end{array}$ & $34(14.0)$ & $96(39.7)$ & $67(27.7)$ & $38(15.7)$ & $7(2.9)$ \\
\hline
\end{tabular}


Tumanggor, R.D., et al. (2021)

Table 3. Average Mean Scores on Demographic Data

\begin{tabular}{|c|c|c|c|c|c|}
\hline \multirow[t]{2}{*}{ Variable } & \multicolumn{2}{|c|}{$\mathbf{n}$} & \multirow[t]{2}{*}{ p Value } & \multirow[t]{2}{*}{ Mean \pm SD } & \multirow[t]{2}{*}{ p Value } \\
\hline & Low & High & & & \\
\hline \multicolumn{6}{|l|}{ Age } \\
\hline $15-25$ & $60(27.3)$ & $160(72.7)$ & $0.025^{*}$ & $20.83 \pm 4.955$ & 0.093 \\
\hline $26-35$ & $2(13.3)$ & $13(86.7)$ & & $20.13 \pm 3.482$ & \\
\hline $36-45$ & $4(80.0)$ & $1(20.0)$ & & $15.60 \pm 2.966$ & \\
\hline $46-55$ & $1(50.0)$ & $1(50.0)$ & & $18.00 \pm 1.414$ & \\
\hline$>56$ & - & - & & & \\
\hline \multicolumn{6}{|l|}{ Occupation } \\
\hline Student & $52(29.1)$ & $12(70.9)$ & 0.231 & $20.91 \pm 5.122$ & 0.269 \\
\hline Unemployment & $3(37.5)$ & $5(62.5)$ & & $21.50 \pm 5.292$ & \\
\hline Nurse & $4(18.2)$ & $18(81.8)$ & & $21.14 \pm 3.550$ & \\
\hline Lecturer / Teacher & $1(8.3)$ & $11(91.7)$ & & $20.17 \pm 2.918$ & \\
\hline Employees & $3(23.1)$ & $10(76.9)$ & & $18.15 \pm 4.337$ & \\
\hline Nun & 0 & $2(100)$ & & $19.00 \pm 0.001$ & \\
\hline Housewife & $2(66,7)$ & $1(33.3)$ & & $18.67 \pm 4.726$ & \\
\hline Civil servants & $2(66,7)$ & $1(33.3)$ & & $15.33 \pm 4.041$ & \\
\hline \multicolumn{6}{|c|}{ The closest person affected by COVID-19 } \\
\hline Present & $16(31.4)$ & $35(68.6)$ & 0.597 & $51 \pm 20.69$ & 0.956 \\
\hline Absent & $51(26.7)$ & $140(73.3)$ & & $191 \pm 20.64$ & \\
\hline \multicolumn{6}{|l|}{ Comorbidities } \\
\hline Present & $6(22.2)$ & $21(77.8)$ & 0.649 & $21.96 \pm 5.523$ & 0.139 \\
\hline Absent & $61(28.4)$ & $154(71.6)$ & & $20.49 \pm 4.781$ & \\
\hline
\end{tabular}

Indonesia, were recruited as respondents for this study. The survey was promoted through WhatsApp and text all the potential research samples on November 2020.

The shared link was distributed along with the message that contained the research title, the name of the researchers and the criteria for women eligible to participate. The questionnaire consisted of three parts, namely approval to participate, demographic data, and the fear of COVID-19 instrument.

Subsequently, data analysis was carried out using Statistical Package for the Social Sciences (SPSS) version 23 (Dunn et al., 2017). The mean scores of each item and overall items were calculated and compared based on demographic data using a t-test for two variables and analysis of variance (ANOVA) for three or more variables. Furthermore, the scores obtained were categorized into low and high fear levels based on the overall mean, where scores from 0-17 were categorized as low-level fear and 18-35 as high-level fear since the total score was 35 . Therefore, the authors divided the score into two categories (Hastono, 2016).

The respondents stated their agreement terms and consent to participate by ticking the agreement terms and conditions in Google form before proceeding to the survey's main instruments. Informed consent was obtained electronically from all participants. This study passed the ethical approval from the Ethic Committee of Universitas Sumatera Utara with reference number 728/KEP/ USU/2020 on November, 24.

\section{Results}

Based on the results obtained, it was identified that most of the subjects were within the age range of $15-25$ years $(90.9 \%)$ and $74 \%$ were students. The number of respondents with comorbidities was only $11.2 \%$ and almost a quarter of them knew other infected individuals. Moreover, the fear level among the female shows that most of the respondents had high fear level (72.3\%) and $27.7 \%$ has low level fear as shown in table 1.

Table 2 shows the detailed question items on the fear of COVID-19 instrument. It is seen that the subjects agreed on over $30 \%$ of the items, but disagreed on most of the items, ranging from $30 \%$ to $60 \%$. From a total of 242 respondents, Q1 shows that most participants agreed $(41 \%)$ and strongly agreed $(26.9 \%)$ on the statement of fear of the COVID-19 virus. Furthermore, it is seen from Q2, where $51.2 \%$ of the subjects agreed that they feel uncomfortable when thinking about the COVID-19 virus and $32.2 \%$ expressed fear of dying from COVID-19. However, on other question items such as in Q3, 62\% disagreed on having moist hands when thinking about COVID-19 and $1 \%$ stated that 
Original Article

Fear of Covid-19 Related Factors among Females

Table 4. Comparison between the Mean Score of Instrument Items and Demographic Data

\begin{tabular}{|c|c|c|c|c|c|c|c|}
\hline Demography & Q1 & Q2 & Q3 & Q4 & Q5 & Q6 & Q7 \\
\hline \multicolumn{8}{|l|}{ Age } \\
\hline $15-25$ & $\begin{array}{c}3.79 \pm \\
1.061\end{array}$ & $\begin{array}{l}3.74 \pm \\
1.044\end{array}$ & $\begin{array}{l}2.29 \pm \\
0.792\end{array}$ & $\begin{array}{c}3.27 \pm \\
1.141\end{array}$ & $\begin{array}{l}2.84 \pm \\
1.037\end{array}$ & $\begin{array}{l}2.33 \pm \\
0.898\end{array}$ & $\begin{array}{c}2.57 \pm \\
1.020\end{array}$ \\
\hline $26-35$ & $\begin{array}{l}4.13 \pm \\
0.640\end{array}$ & $\begin{array}{l}3.93 \pm \\
0.884\end{array}$ & $\begin{array}{c}2.20 \pm \\
0.676\end{array}$ & $\begin{array}{c}2.80 \pm \\
1.014\end{array}$ & $\begin{array}{l}2.67 \pm \\
0.976\end{array}$ & $\begin{array}{l}2.07 \pm \\
0.884\end{array}$ & $\begin{array}{l}2.33 \pm \\
0.900\end{array}$ \\
\hline $36-45$ & $\begin{array}{l}3.00 \pm \\
0.707\end{array}$ & $\begin{array}{l}3.40 \pm \\
0.894\end{array}$ & $\begin{array}{l}1.80 \pm \\
0.447\end{array}$ & $\begin{array}{l}1.40 \pm \\
0.584\end{array}$ & $\begin{array}{l}2.20 \pm \\
0.837\end{array}$ & $\begin{array}{l}1.80 \pm \\
0.447\end{array}$ & $\begin{array}{l}2.00 \pm \\
0.707\end{array}$ \\
\hline $46-55$ & $\begin{array}{l}4.00 \pm \\
0.001\end{array}$ & $\begin{array}{l}4.00 \pm \\
0.001\end{array}$ & $\begin{array}{c}4.00 \pm \\
1.414\end{array}$ & $\begin{array}{l}1.50 \pm \\
0.707\end{array}$ & $\begin{array}{l}1.50 \pm \\
0.707\end{array}$ & $\begin{array}{l}1.50 \pm \\
0.707\end{array}$ & $\begin{array}{l}1.50 \pm \\
0.707\end{array}$ \\
\hline$>56$ & - & - & - & - & - & - & - \\
\hline p Value & 0.202 & 0.753 & $0.010^{*}$ & $0.001^{*}$ & 0.143 & 0.223 & 0.222 \\
\hline \multicolumn{8}{|l|}{ Occupation } \\
\hline Student & $\begin{array}{c}3.82 \pm \\
1.066\end{array}$ & $\begin{array}{c}3.73 \pm \\
1.063\end{array}$ & $\begin{array}{c}2.30 \pm \\
0.805\end{array}$ & $\begin{array}{c}3.28 \pm \\
1.167\end{array}$ & $\begin{array}{c}2.89 \pm \\
1.070\end{array}$ & $\begin{array}{c}2.31 \pm \\
0.932\end{array}$ & $\begin{array}{c}2.58 \pm \\
1.054\end{array}$ \\
\hline Unemployment & $\begin{array}{c}4.00 \pm \\
1.069\end{array}$ & $\begin{array}{c}3.88 \pm \\
1.246\end{array}$ & $\begin{array}{c}2.63 \pm \\
0.744\end{array}$ & $\begin{array}{l}3.38 \pm \\
1.302\end{array}$ & $\begin{array}{c}2.63 \pm \\
1.061\end{array}$ & $\begin{array}{c}2.38 \pm \\
0.744\end{array}$ & $\begin{array}{l}2.63 \pm \\
0.916\end{array}$ \\
\hline Nurse & $\begin{array}{l}3.86 \pm \\
0.834\end{array}$ & $\begin{array}{l}3.86 \pm \\
0.774\end{array}$ & $\begin{array}{l}2.27 \pm \\
0.827\end{array}$ & $\begin{array}{c}3.27 \pm \\
1.032\end{array}$ & $\begin{array}{l}2.68 \pm \\
0.780\end{array}$ & $\begin{array}{l}2.50 \pm \\
0.740\end{array}$ & $\begin{array}{l}2.68 \pm \\
0.945\end{array}$ \\
\hline Lecturer / Teacher & $\begin{array}{l}3.58 \pm \\
0.900\end{array}$ & $\begin{array}{l}3.92 \pm \\
0.669\end{array}$ & $\begin{array}{c}2.67 \pm \\
0.888\end{array}$ & $\begin{array}{c}2.58 \pm \\
0.793\end{array}$ & $\begin{array}{c}2.67 \pm \\
1.073\end{array}$ & $\begin{array}{l}2.33 \pm \\
0.888\end{array}$ & $\begin{array}{l}2.42 \pm \\
0.900\end{array}$ \\
\hline Employees & $\begin{array}{l}3.54 \pm \\
1.127\end{array}$ & $\begin{array}{c}3.77 \pm \\
1.166\end{array}$ & $\begin{array}{l}1.85 \pm \\
0.555\end{array}$ & $\begin{array}{c}2.69 \pm \\
1.109\end{array}$ & $\begin{array}{l}2.38 \pm \\
0.961\end{array}$ & $\begin{array}{l}1.85 \pm \\
0.689\end{array}$ & $\begin{array}{c}2.08 \pm \\
0.760\end{array}$ \\
\hline Nun & $\begin{array}{l}4.50 \pm \\
0.707\end{array}$ & $\begin{array}{l}2.50 \pm \\
0.707\end{array}$ & $\begin{array}{l}2.00 \pm \\
0.001\end{array}$ & $\begin{array}{l}4.00 \pm \\
0.001\end{array}$ & $\begin{array}{l}2.50 \pm \\
0.707\end{array}$ & $\begin{array}{l}1.50 \pm \\
0.707\end{array}$ & $\begin{array}{l}2.00 \pm \\
0.001\end{array}$ \\
\hline Housewife & $\begin{array}{c}3.67 \pm \\
1.155\end{array}$ & $\begin{array}{l}3.33 \pm \\
1.155\end{array}$ & $\begin{array}{l}2.33 \pm \\
0.557\end{array}$ & $\begin{array}{l}2.33 \pm \\
0.577\end{array}$ & $\begin{array}{c}2.33 \pm \\
0.577\end{array}$ & $\begin{array}{c}2,33 \pm \\
0.577\end{array}$ & $\begin{array}{l}2.33 \pm \\
0.577\end{array}$ \\
\hline Civil servants & $\begin{array}{c}3.00 \pm \\
1.000\end{array}$ & $\begin{array}{l}3.67 \pm \\
0.557\end{array}$ & $\begin{array}{l}1.67 \pm \\
0.577\end{array}$ & $\begin{array}{l}1.00 \pm \\
0.001\end{array}$ & $\begin{array}{c}2.33 \pm \\
1.155\end{array}$ & $\begin{array}{l}1.67 \pm \\
0.577\end{array}$ & $\begin{array}{c}2.00 \pm \\
1.000\end{array}$ \\
\hline p Value & 0.719 & 0.758 & 0.176 & $0.004^{*}$ & 0.604 & 0.364 & 0.644 \\
\hline \multicolumn{8}{|c|}{ The closest person affected by COVID-19 } \\
\hline Present & $\begin{array}{l}3.90 \pm \\
0.922\end{array}$ & $\begin{array}{l}3.86 \pm \\
0.895\end{array}$ & $\begin{array}{l}2.37 \pm \\
0.937\end{array}$ & $\begin{array}{c}3.29 \pm \\
1.316\end{array}$ & $\begin{array}{l}2.80 \pm \\
1 ., 265\end{array}$ & $\begin{array}{c}2.12 \pm \\
1.032\end{array}$ & $\begin{array}{c}2.33 \pm \\
1.211\end{array}$ \\
\hline Absent & $\begin{array}{c}3.77 \pm \\
1.066\end{array}$ & $\begin{array}{c}3.71 \pm \\
1.059\end{array}$ & $\begin{array}{l}2.27 \pm \\
0.759\end{array}$ & $\begin{array}{l}3.16 \pm \\
1.122\end{array}$ & $\begin{array}{l}2.81 \pm \\
0.967\end{array}$ & $\begin{array}{l}2.34 \pm \\
0.849\end{array}$ & $\begin{array}{l}2.59 \pm \\
0.946\end{array}$ \\
\hline$p$ Value & 0.419 & 0.353 & 0.403 & 0.456 & 0.988 & 0.114 & 0.105 \\
\hline \multicolumn{8}{|l|}{ Comorbidities } \\
\hline Present & $\begin{array}{l}3.90 \pm \\
0.922\end{array}$ & $\begin{array}{l}3.86 \pm \\
0.895\end{array}$ & $\begin{array}{l}2.37 \pm \\
0.937\end{array}$ & $\begin{array}{c}3.29 \pm \\
1.316\end{array}$ & $\begin{array}{c}2.80 \pm \\
1.265\end{array}$ & $\begin{array}{c}2.12 \pm \\
1.032\end{array}$ & $\begin{array}{c}2.33 \pm \\
1.211\end{array}$ \\
\hline Absent & $\begin{array}{c}3.77 \pm \\
1.066\end{array}$ & $\begin{array}{c}3.71 \pm \\
1.059\end{array}$ & $\begin{array}{c}2.27 \pm \\
0.759\end{array}$ & $\begin{array}{c}3.16 \pm \\
1.122\end{array}$ & $\begin{array}{l}2.81 \pm \\
0.967\end{array}$ & $\begin{array}{l}2.34 \pm \\
0.849\end{array}$ & $\begin{array}{c}2.59 \pm \\
0.946\end{array}$ \\
\hline$p$ Value & 0.419 & 0.353 & 0.403 & 0.456 & 0.988 & 0.114 & 0.105 \\
\hline
\end{tabular}

they strongly agree with the psychological condition of having moist hands. In addition, on item Q5, 33.1\% stated that they did not feel nervous when watching news about COVID-19, 47. 1\% did not experience sleep disturbances and $39.7 \%$ did not feel any heart palpitations when thinking about COVID-19.

Based on the statistical analysis presented in table 3 , it was discovered that the $P$ value obtained was $<0.05$ from the overall mean score for each variable in the demographic data. This shows that the age of the respondents significantly influenced their fear of COVID-19. Females 15-25 years of age experienced the highest levels of mean fear.

Table 4 shows the comparison between instrument question items with four demographic data variables, which included age, occupation, 
comorbidities and the presence or absence of the closest individual with COVID-19. The P-value 0.05 obtained from items Q3 and Q4 indicate a significant relationship between both items and the age variable. Furthermore, there was a significant relationship between Q4 and the occupation variable.

\section{Discussion}

The results obtained in this study indicate that most of the respondents were within a young age range (15-25 years) and were students. Furthermore, from the analysis, it was discovered that age had a significant effect on women's fear of COVID-19, with younger women experiencing higher levels of mean fear. This is consistent with past findings, during the COVID-19 pandemic, where females were proven to be a gender group that experienced high levels of fear of the virus (Doshi, 2020). However, statistically the mortality rate due to COVID-19 is dominated by men (Williamson et al., 2020), the COVID-19 infection rate for both genders showed the same percentage. Given the level of fear identified, women's health should remain a priority during the COVID-19 pandemic, both physically and mentally, despite less relative risk of mortality. Pregnant women are at risk of being infected with COVID-19 (C. Huang et al., 2020), and further studies to explore fear levels in this group are indicated, given that this study identified relatively higher fear levels in the population of younger women.

Mentally, several factors contribute to causing psychological pressure due to the weak position of women in the industrial sector, including the conflicting roles at times of being the main breadwinners and becoming household caregivers (Gausman \& Langer, 2020). Indirectly, these factors cause high levels of base distress, and may affect susceptibility to the experience of greater fear of COVID-19. Furthermore, this disease has shown to infect individuals with certain immune conditions and individuals that are easily depressed psychologically are more prone to decreased immunity compared to those who are not easily depressed (Zhang et al, 2020).

In this study, it was identified that the questions related to having moist hands when thinking about the COVID-19 virus and fear of death from the virus had a significant relationship with mean age. For those in the age range 46-55, fear of the virus and discomfort thinking about it had significant resonance. Fear is an individual human response that usually occurs throughout life, because the human brain processes stressors as a stimulus, which causes stress and fear (Maeng, L \& Milad, 2015). Fear has escalated as a concrete threat as existed since the COVID-19 pandemic was declared as a world health problem. This fear was increasingly awakened due to the new nature of the virus, which at the time of the study had no developed vaccine. Fear included a focus on the socio-economic impact due to social distancing requirements which caused many businesses to close and massive layoffs (Nicola et al., 2020).

In addition, according to the analysis of the overall mean score, showing that $72.3 \%$ samples had high-level fear and $27.7 \%$ has low-level fear, fear is a significant issue among females in Medan, Indonesia. This research result is consistent with other studies that have identified that women revealed high levels of fear, which in other studies represented higher levels compared to men during the COVID-19 outbreaks (Gausman \& Langer, 2020; Labrague \& de los Santos, 2020; Rajkumar, 2020; Reznik et al., 2020; Williamson et al., 2020). Effect of Women's Age on Fear of COVID-19

According to the data, this study showed that women's age has an impact on their fear response to COVID-19 infection. Studies have shown that there is a link between age and the fear of being infected with certain diseases, leading to death in young women (Fitzpatrick et al., 2020). Consistent with the finding that identified greater mean fear among the younger women in this study, being a student had a significant relationship with experiencing higher mean fear. Therefore, being student and young are factors considered to be vulnerability factors to the fear of COVID-19. In addition, old age has shown to have a significant effect on the ease of infection (Pan et al., 2020), with a higher mortality rate in men. Therefore, old age is one of the biggest risk factors for the vulnerability of being infected with COVID-19 in both men and women. This may explain the identified fear of the virus in the older group and discomfort when thinking about the virus. This has implications as discomfort thinking about the virus may lead to denial and lower rates of participation in preventive measures.

\section{Limitations}

The age of the sample and the disproportionate number of participants who were identified as students may have been related to the online survey method. Further study is indicated using different surveying methods to balance these limitations.

\section{Conclusion}

The findings of this study identified that there was a significant relationship between age and occupation with the fear of COVID-19 in women. However, a total of 242 respondents filled out the online survey, the results cannot be used as a general reference for the entire population of women in Medan. Therefore, further and in-depth studies are needed to obtain more information about the factors that influence women's fear of the life-threatening pandemic outbreak. In addition, these results provided an overview of the importance of specific women's health-based interventions focused on mental wellbeing. Furthermore, Indonesia's national health policy still targets women's health at the level of mothers and children clinically, not those with any sign of acute or chronic illnesses as described in the 
fear of COVID-19 instrument. This requires further consideration.

\section{References}

Ahorsu, D. K., Lin, C. Y., Imani, V., Saffari, M., Griffiths, M. D., \& Pakpour, A. H. (2020). The fear of COVID-19 scale: Development and initial validation. International Journal of Mental Health and Addiction, 1-9. https://doi. org/10.1007/s11469-020-00270-8

Broche-Pérez Y, Fernández-Fleites Z, Jiménez-Puig $E$, Fernández-Castillo $E$, \& Rodríguez-Martin B. (2020). Gender and Fear of COVID-19 in a Cuban Population Sample. International Journal of Mental Health and Addiction [revista en Internet] 2020 [acceso 11 de octubre de 2020]; (1): 1-9. International Journal of Mental Health and Addiction, 1, 1-9. https://www. ncbi.nlm.nih.gov/pmc/articles/PMC7292241/ pdf/11469_2020_Article_343.pdf

Conti, A., Clari, M., Arese, S., Bandini, B., Cavallaro, L., Mozzone, S., Vellone, E., Frigerio, S., \& Campagna, S. (2020). Validation and psychometric evaluation of the Italian version of the Spinal Cord Injury Secondary Conditions Scale. Spinal Cord, 58(4), 496-503. https:// doi.org/10.1038/s41393-019-0384-z

Cullen, W., Gulati, G., \& Kelly, B. D. (2020). Mental health in the COVID-19 pandemic. QJM : Monthly Journal of the Association of Physicians, 113(5), 311-312. https://doi. org/10.1093/qjmed/hcaa110

Doshi, D., Karunakar, P., Sukhabogi, J. R., Prasanna, J. S., \& Mahajan, S. V. (2020). Assessing Coronavirus fear in Indian population using the fear of COVID-19 scale. International Journal of Mental Health and Addiction, 19(6), 23832391. https://doi.org/10.1007/s11469-02000332-x

Dunn, P. K., Carey, M. D., Farrar, M. B., Richardson, A. M., \& McDonald, C. (2017). Introductory statistics textbooks and the GAISE recommendations. American Statistician, 71(4), 326-335. https://doi.org/10.1080/00031 305.2016 .1251972

Fitzpatrick, K. M., Harris, C., \& Drawve, G. (2020). Living in the midst of fear: Depressive symptomatology among US adults during the COVID-19 pandemic. Depression and Anxiety, 37(10), 957-964. https://doi.org/10.1002/ da. 23080

Garfin, D. R., Silver, R. C., \& Holman, E. A. (2020). The novel coronavirus (COVID-2019) outbreak: Amplification of public health consequences by media exposure. Health Psychology, 39(5), 355-357. https://doi.org/10.1037/hea0000875

Gausman, J., \& Langer, A. (2020). Sex and gender disparities in the COVID-19 pandemic. Journal of Women's Health, 29(4), 465-466. https:// doi.org/10.1089/jwh.2020.8472

Hastono, S. P. (2016). Analisa Data Bidang
Kesehatan. Rajawali Pers.

Huang, C., Wang, Y., Li, X., Ren, L., Zhao, J., Hu, Y., Zhang, L., Fan, G., Xu, J., Gu, X., Cheng, Z., Yu, T., Xia, J., Wei, Y., Wu, W., Xie, X., Yin, W., Li, H., Liu, M., ... Cao, B. (2020). Clinical features of patients infected with 2019 novel coronavirus in Wuhan, China. The Lancet, 395(10223), 497-506. https://doi.org/10.1016/ S0140-6736(20)30183-5

Huang, Y., \& Zhao, N. (2020). Generalized anxiety disorder, depressive symptoms and sleep quality during COVID-19 outbreak in China: A web-based cross-sectional survey. Psychiatry research, 288. https://doi.org/10.1016/j. psychres.2020.112954

Ifdil, I., Fadli, R. P., Suranata, K., Zola, N., \& Ardi, Z. (2020). Online mental health services in Indonesia during the COVID-19 outbreak. Asian Journal of Psychiatry, 51. https://doi. org/10.1016/j.ajp.2020.102153

Labrague, L. J., \& de los Santos, J. (2020). Fear of COVID-19, psychological distress, work satisfaction and turnover intention among frontline nurses. Journal of Nursing Management, 1-18. https://doi.org/10.1111/ jonm.13168

Lebel, S., Mutsaers, B., Tomei, C., Leclair, C. S., Jones, G., Petricone-Westwood, D., Rutkowski, N., Ta, V., Trudel, G., Laflamme, S. Z., Lavigne, A. A., \& Dinkel, A. (2020). Health anxiety and illness-related fears across diverse chronic illnesses: A systematic review on conceptualization, measurement, prevalence, course, and correlates. In PLoS ONE 15,(7). https://doi.org/10.1371/journal.pone.0234124

Lissek, S., Pine, D. S., \& Grillon, C. (2006). The strong situation: A potential impediment to studying the psychobiology and pharmacology of anxiety disorders. Biological Psychology, 72(3), 265-270. https://doi.org/10.1016/j. biopsycho.2005.11.004

Maeng, L \& Milad, M. (2015). Sex differences in anxiety disorders: interactions between fear, stress, and gonadal hormones. Hormones and Behavior, 106-117. https://doi.org/10.1016/j. yhbeh.2015.04.002.Sex

Mertens, G., Gerritsen, L., Duijndam, S., Salemink, E., \& Engelhard, I. M. (2020). Fear of the coronavirus (COVID-19): Predictors in an online study conducted in March 2020. Journal of Anxiety Disorders, 74. https://doi. org/10.1016/j.janxdis.2020.102258

Mikkola, R., Huhtala, H., \& Paavilainen, E. (2017). Work-related fear and the threats of fear among emergency department nursing staff and physicians in Finland. Journal of Clinical Nursing, 26(19-20), 2953-2963. https://doi. org/10.1111/jocn.13633

Nicola, M., Alsafi, Z., Sohrabi, C., Kerwan, A., AlJabir, A., Iosifidis, C., Agha, M., \& Agha, R. (2020). The socio-economic implications of the coronavirus pandemic (COVID-19): A review. 
International Journal of Surgery, 78, 185-193. https://doi.org/10.1016/j.ijsu.2020.04.018

Pan, L., Mu, M., Yang, P., Sun, Y., Wang, R., Yan, J., Li, P., Hu, B., Wang, J., Hu, C., Jin, Y., Niu, X., Ping, R., Du, Y., Li, T., Xu, G., Hu, Q., \& Tu, L. (2020). Clinical characteristics of COVID-19 patients with digestive symptoms in Hubei, China: A descriptive, cross-sectional, multicenter study. American Journal of Gastroenterology, 115(5), 766-773. https://doi. org/10.14309/ajg.0000000000000620

Pang, N. T. P., Kamu, A., Hambali, N. L. B., Mun, H. C., Kassim, M. A., Mohamed, N. H., Ayu, F., Rahim, S. S. S. A., Omar, A., \& Jeffree, M. S. (2020). Malay Version of the Fear of COVID-19 Scale: Validity and Reliability. International Journal of Mental Health and Addiction, 20. https://doi.org/10.1007/s11469-020-00355-4

Pieh, C., Budimir, S., \& Probst, T. (2020). The effect of age, gender, income, work, and physical activity on mental health during coronavirus disease (COVID-19) lockdown in Austria. Journal of Psychosomatic Research, 136. https://doi. org/10.1016/j.jpsychores.2020.110186

Rajkumar R. P. (2020). COVID-19 and mental health: A review of the existing literature. Asian Journal of Psychiatry, 52. https://doi. org/10.1016/j.ajp.2020.102066

Reznik, A., Gritsenko, V., Konstantinov, V., Khamenka, N., \& Isralowitz, R. (2020). COVID-19 fear in Eastern Europe: Validation of the fear of COVID-19 scale. International Journal of Mental Health and Addiction. https:// doi.org/10.1007/s11469-020-00283-3

Rossi, R., Socci, V., Talevi, D., Mensi, S., Niolu, C., Pacitti, F., Marco, A. Di, Rossi, A., Siracusano, A., \& Lorenzo, G. Di. (2020). COVID-19 pandemic and lockdown measures impact on mental health among the general population in Italy. An N=18147 web-based survey. MedRxiv. https://doi.org/10.1101/2020.04.09.20057802

Satici, B., Gocet-Tekin, E., Deniz, M. E., \& Satici, S. A. (2020). Adaptation of the fear of COVID-19 scale: Its association with psychological distress and life satisfaction in Turkey. International Journal of Mental Health and Addiction 19, 1980-1988. https://doi. org/10.1007/s11469-020-00294-0

Tracy, M., Norris, F. H., \& Galea, S. (2011). Differences in the determinants of posttraumatic stress disorder and depression after a mass traumatic event. Depression and Anxiety, 28(8), 666675. https://doi.org/10.1002/da.20838

Williamson, E. J., Walker, A. J., Bhaskaran, K., Bacon, S., Bates, C., Morton, C. E., Curtis, H. J., Mehrkar, A., Evans, D., Inglesby, P., Cockburn, J., McDonald, H. I., MacKenna, B., Tomlinson, L., Douglas, I. J., Rentsch, C. T., Mathur, R., Wong, A. Y. S., Grieve, R., ... Goldacre, B. (2020). Factors associated with COVID-19-related death using OpenSAFELY. Nature, 584(7821), 430-436. https://doi. org/10.1038/s41586-020-2521-4

Xiang, Y. T., Yang, Y., Li, W., Zhang, L., Zhang, Q., Cheung, T., \& Ng, C. H. (2020). Timely mental health care for the 2019 novel coronavirus outbreak is urgently needed. The Lancet Psychiatry, 7(3), 228-229. https://doi. org/10.1016/S2215-0366(20)30046-8

Zhang, J., Lu, H., Zeng, H., Zhang, S., Du, Q., Jiang, T., \& Du, B. (2020). The differential psychological distress of populations affected by the COVID-19 pandemic. Brain, Behavior, and Immunity, 87, 49-50. https://doi. org/10.1016/j.bbi.2020.04.031 